Tóth Réka

\title{
Egy hiperkorszak mélységei
}

Han, Byung-Chul. 2019. A kiégés társadalma. Ford. Miklódy Dóra - Simon-Szabó Ágnes. Budapest: Typotex. 112 oldal, 2200 Ft.

Byung-Chul Han dél-koreai születésü társadalomfilozófus, kultúrteoretikus, aki a húszas éveiben Németországba költözött és napjainkban is Berlinben folytatja professzori tevékenységét. Olyan jelenségeket vizsgál, melyek az általa „kiégés társadalmára” (The Burnout Society / Müdigkeitsgesellschaft) és az „átlátszóság társadalmára” (Transparenzgesellschaft) keresztelt közösségekhez kapcsolhatóak, többek között a hiperaktivitást, a popkultúra árnyoldalait, az egyes személyiségzavarokat, illetve a teljesítménykényszert és az annak következtében állandósult fáradtságot. A 2012-ben megjelenő, tizenegy nyelvre lefordított $A$ kiégés társadalma is ezeket a témákat boncolgatja, igen eredeti módon. A következőkben az egyes fejezetek rövid áttekintését nyújtjuk.

Han könyvét alapvetően két egymásból következő korszak bemutatása határozza meg, a szerző minden fejezetben e két korszak egy-egy központi jelenségét elemzi. Az egyiket immunológiai korszaknak nevezi, mely névvel tulajdonképpen az elmúlt századot írja körül, a másikat posztimmunológiai korszaknak. Az első két fejezet, „A neuronális erőszak” és a „Túl a fegyelmezo társadalmon” bővebben tanulmányozza e két korszakban élő alanyok viselkedését, főként annak mentén, hogy mi jellemzi az Idegenre, a Másikra adott reakciójukat. Az immunológiai korszakot Han a „vírusok koraként” is emlegeti, utalva ezzel az Idegennel való megküzdés, a támadás-védekezés, barát-ellenség és a háborúk dialektikai játékára. Majd e játék legföbb veszélyére is kitér: természetesen ez a fajta erőszakkal átitatott dialektika vakságot okozhat, hiszen ennek következtében egy természetes védelmi vonalat húzunk fel magunk köré, védekezünk minden ellen, ami kívülről érkezik felénk. Kizárjuk a Másikat. Ennek veszélyét a szerző ugyan megemlíti, de részletesebb leírására nem vállalkozik, feltehetőleg azért, mert megpróbálja elkerülni az erkölcsfilozófiai kliséket, és végképp nem akar elköteleződni vagy épp elhatárolódni egyik vagy másik morális paradigma mellett/ellen. Továbbá a mű nem akar történelmi rekonstrukciót kínálni, nem említi például az immunológiai korszak gondolkodásának elemzésénél annak szélsőséges „hozományát”, a totalitárius berendezkedések gyakorlatát, annak ellenére, hogy az Idegen és a Másik összefüggéseinek vizsgálata általában megkívánja, sőt kényszeríti erre a szerzőket. Han a korszakot inkább egy másik, általa megnevezett korszak viszonyában vizsgálja és ezzel új megvilágításba helyezi.

A másik korszak, ami az előzőt követi, és amit jelenleg is élünk, illetve tapasztalunk, a posztimmunológia korszaka, melyben a korábbi Másik helyét az ugyanaz veszi át. Vele 
kapcsolatban a gyanakvás helyett inkább a hozzá való közeledést választjuk. Nem tekintjük tőlünk különbözőnek és ilyen módon félelmet keltőnek, ugyanis a xenofóbia ismeretlen e kor számára, innen nézve ez a korszak alapvetően vendégszeretőbbnek minősül bármelyik korábbinál. Arra kérdésre, hogy vajon kortársaink migrációra adott sokszor elidegenítő, eltárgyiasító immunválasza mennyiben illeszthető bele ebbe a képbe, Han azt válaszolja: nagyon is beleillik, ugyanis a posztimmunológia korában a bevándorlót inkább teherként, mintsem külső fenyegetésként szokás elgondolni. Itt megjegyezhetjük, hogy Han - néhol úgy tủnik - nem akar tudomást venni az újfajta, a migrációval kapcsolatos xenofóbia fokozatos erősödéséről, vagy pusztán csak nem gondolja, hogy a mai újnacionalista eszmék összeegyeztethetőek a korábbi, immunológiai korszak hasonló jellegű eszméivel, mert talán azt feltételezi, hogy azok egy posztimmunológiai korszakban többé már nem válhatnak univerzálisakká. Persze az is elképzelhető, hogy a németek migrációpolitikája is hatást gyakorolt rá.

Han szerint tehát a posztimmunológiai korszak az ugyanaz korszaka. De mi a más és mi lehet hozzá képest az ugyanaz? A másság, az idegenség hani értelemben olyan külső, rajtam kívülállóságot jelent, amelyre az immunológiai korban egy természetes immunválasz született: a védekezés, majd az ebből fakadó támadás, tehát egyfajta negatív reakció, a Másikkal való negatív dialektika. Ehhez képest a posztimmunológiai kor ugyanazkultusza a pozitivitás dialektikája, az ugyanaz ugyanazzal való összekapcsolódása, ahol én és a Másik között már nincs érdemi különbség, eggyé válok vele és ő is eggyé válik velem. Ez az egyesülés egyik oldalon sem vált ki támadó reakciót, azonban mégsem nevezhető veszély nélkülinek. A szerző itt Baudrillard-ra hivatkozik, aki az ugyanaz totalitarizmusával foglalkozik: „Aki ugyanattól él, ugyanattól is pusztul el.” Han azzal magyarázza a baudrillard-i gondolatot, hogy ez a fajta önfelszámolás azért történhet meg a posztimmunológai korban, mert reakciónk az ugyanazra nem természetes immunválasz, azaz nem ösztönös reakció, sokkal inkább egy tanuláson alapuló természetellenes cselekedet. (15) Ettől még megtörténhet, hogy egy idő után rutinná válik, és ennek következtében belefáradunk az - Han által „hibridizált dialektikának” is nevezett - ugyanazzal létrejött kapcsolatunkba. Ezt a „hibridizált dialektikát” egyébiránt sokszor láthatjuk megjelenni a posztmodern kor zavartságában is, a kilátástalanság vagy az ellenségnélküliség leképeződéseként.

Han szerint a posztimmunológiai korban, amikor a más mint olyan helyét az ugyanaz foglalja el, az erőszak nem feltétlenül hagy alább, csak láthatatlanná válik. A posztimmunológiai kor dialektikája ugyanis előbb-utóbb, ahogy Han mondja, neuronális eröszakhoz vezet (9-20). Az erőszak azért is láthatatlan a posztimmunológiai korban, mert gyakorlatilag megszünik a kint és a bent, azaz én és az Idegen addig kialakult két körbezárt burka, és kiteljesedésének nem marad konkrét helye. De Han szerint attól

1 Baudrillard 1997, 58. 
még igenis létezik, sőt még alattomosabban járja át az én és az én általam befogadott ugyanaz közös szféráját. Ez a fajta erőszak nem likvidálja egyik felet sem, nem kirekesztő, azonban eltelít és kimerít bennünket.

Han a posztimmunológiai kor újkeletű pszichés rendellenességeit is e kimerültség számlájára írja. Sem a depresszió, sem a hiperaktivitás, sem a bipoláris személyiségzavar nem jöhet létre a virális, azaz az immunológiai korszakban, mert ezek mind egyfajta belső, láthatatlan erőszak fejleményei, egy olyan erőszaké, ami a „pozitivitás túltengését” (28) okozza bennünk. A szerző egyébiránt a hiperaktivitást tekinti a posztimmunológiai korszak szimptómájának, e korszak problémáit leghitelesebben ábrázoló immunválasznak. A könyv kezdő sorai is erre utalnak: Han az önkizsákmányolás jelképével, a kafkai Prométheusz és a sas képével utal a posztimmunológiai korszakban megjelenő teljesítő alanyra (de esetünkben nem a sas váj ki belőlünk egy darabot minden nap, hanem önmagunkat marcangoljuk), azaz az önfelemésztő hiperaktív társadalom jelképére.

Az immunológiai és a posztimmunológiai korszak további sajátosságairól a következő fejezetekben olvashatunk, ahol a szerző e két korszakra jellemző sajátosságok bemutatásával próbálja kiemelni árnyoldalaikat is: társadalmi szinten megjelennek többek között a fegyelmezö társadalom és a teljesitményelvü társadalom jellegzetes tulajdonságai, aztán az egyének szintjén az engedelmes alany és a teljesitö alany sajátosságai, majd ismét szintet ugrunk és „A mélyreható unalom” fejezetben a negativitás és pozitivitás társadalmának jelenségeit és fegyelmező erejét hasonlíthatjuk össze. Az egyik oldalon a jeligék tilalmak lesznek, mint például a „nem!” és a „maradj távol!”, míg a másik oldalon a „kell!” és ehhez hasonló buzdítások jelennek meg. Han az immunológiai korszak tiltó/ fegyelmező erejének blokkoló hatására hívja fel figyelmünket. Amellett foglal állást, hogy ez a blokkolás bizony gátat szabhat a teljesítmény növekedésének, amint ezt a történelem is igazolja. A posztimmunológiai korszakban már ráébredtek arra, hogy a tiltás/fegyelmezés csupán ideig-óráig hathat, a hatalom hosszabbtávú fenntartásához más módszerek kellenek. A fegyelmező intézmények működtetői rájöttek arra, hogy a negatív tiltás nem képes egy jól mủködő társadalom létrehozására, a tiltásnál fontosabb a pozitivitás kihangsúlyozása. Hatékonyabb, ha a buzdítás kerül előtérbe a képességeink felszínre hívásával egyetemben, a „nem szabad” jelige helyett a „lehet” vagy „kellene” jeligével együtt.

Han láthatóan nem elfogult egyik immunológiai korral szemben sem, ennek köszönhetően remek rálátása van a két korszak közti átmenetekre is, világosan megmutatja, hogy az immunológiai korszakból mely viselkedési normák hagyományozódtak tovább a posztimmunológiai korszakba, illetve azt is, hogy ezen normák - bár ideológiailag jól megalapozottá és potenciálisan müködőképesé tehetik a társadalmat - a valóságban nem így hatnak. Mégpedig azért, mert az immunológiai korban elsajátított viselkedési 
normákat, hagyományokat nem tudjuk teljesen magunk mögött hagyni. Ezzel egyébként a szerző többek között Foucault véleményét osztja, aki szerint a fegyelmező társadalmakban elsajátított magatartásformák továbböröklődnek és akár egy új, későbbi paradigma árnyékában is megjelenhetnek. ${ }^{2}$ (21) Szerinte ez a fajta továbböröklődés azt jelenti, hogy az új, posztimmunológiai korszakban alkalmazott pozitív normák nem érvénytelenítik az immunológiai korszakban kialakult negatív normákat. A fegyelmező társadalom teljesítő alanya tehát egy új korszakban is engedelmes marad, mert jelenléte a fegyelmező szakaszban erre predesztinálja. De mivel a posztimmunológiai korszakban nincs, aki fegyelmezze, ez az engedelmesség önmagának-engedelmességgé, egy teljesítménykényszer vezérelte önfegyelmezéssé alakul át, amiben az alany egyszerre tölti be a ragadozó sas és az áldozat Prométheusz szerepét. Han az önmagunknak való engedelmesség túlhajszolásából, az alkotó- és tetterő kifáradásából eredezteti a depresszió kialakulását is. Szerinte ez akkor alakul ki az emberben, amikor ráébred, hogy a „semmi sem lehetetlen világában létezik a lehetetlen” (20), azonban ezt a belátást nem képes feldolgozni.

Han a „Vita activa” című fejezetben megpróbálja részletezni, hogy e mentális elváltozások pontosan hogyan jönnek létre. Arra jut, hogy a teljesítménykényszer állatiassá teszi az embert, ami azzal jár, hogy mentálisan visszafejlődik. Az állat szintén hiperaktív, teljesítményorientált, hiperfigyelemmel rendelkezik, ami az állatvilágban természetes. Az embert viszont ez a fajta állati hiperfigyelem jelentősen átalakítja és elveszi tőle az ókorban elsajátított rácsodálkozás képességét, de az újkori karteziánus kételkedés képességét is.

Han a posztimmunológiai korszakot ennek nyomán a nyugtalanság és kényszeresség korának nevezi, és ennek szellemében az arendti munkaelvű társadalomelméletet gondolja tovább. Arendt szerint a vita activa, a cselekvő élet fogalma jelentősen átalakult a századok során és a 20. század közepére teljesen megszűnt. A munkaelvű társadalom korában, amikor a cselekvés minden más lehetőségét kizárjuk, a cselekvő élet fogalma a munka mint cselekvés szintjére süllyed. Ahogy Arendt mondja, az ego az utolsó aktív cselekedetével feladta magát a munka oltárán, hogy jobban funkcionáljon. ${ }^{3}$ Han is e munkaelvű társadalom arendti gondolata mentén halad tovább e korszak leírásában, azonban nem gondolja, hogy a vita activa fogalma teljesen megszünt volna, szerinte inkább csak jelentősen átalakult. Szerinte az ego nem passzív ebben a korszakban, sőt, éppen hogy hiperaktív és ennek értelmében gyakorlatilag elpusztíthatatlannak és szabadnak gondolja magát. Azonban ez a szabadság szerinte puszta illúzió, mert a szabadsághoz épp az szükséges, hogy ez a fajta autisztikus teljesítménygépezet leálljon, ehhez pedig a jó értelemben vett unalom, a „halogatás képessége” elengedhetetlen. (45) A

2 Foucault 1990, 285-308.

3 Arendt 1981, 405-409. 
problémát abban látja, hogy nemcsak a halogatás képessége, de minden érzelem (pl. félelem, gyász), melyek természetes immunreakciók volnának, eltűnnek e gépezet túlműködése következtében. „A mélyreható unalom” fejezet a teljesítménygépezet leállásának, az unatkozásnak, tengetésnek hasznosságát mutatja be, de úgy látja, hogy korunk hiperalanyai már nem képeseḱ ezen állapot előidézésére.

A függelékben a teljesítmény túlműködésének következtében kialakuló, már a könyv elején is említett problémákat elemzi tovább. Itt a posztimmunológiai kor további hátrányairól olvashatunk, egyebek mellett a kanti erkölcsök és kötelességtudat abszolút megszűnéséről és felszámolásáról. Szerinte ebben a korban az individuum már nem tekinthető „engedelmes alanynak”, amennyiben az engedelmességen a Másiknak való engedelmességet értjük. A mai kor alanya önmagának engedelmes, és úgy végzi feladatait, hogy eközben a Másikat igyekszik figyelmen kívül hagyni. A posztimmunológiai kor alanyának perspektívájából a Másik tökéletesen eltűnik, egyszerűen megszabadul tőle. A francia filozófiát sokáig meghatározó Másik felé való odafordulás gondolata tehát e korban értelmét veszti. Han drasztikusan különbözteti meg egymástól a franciákra jellemző Másik-filozófiát és a posztimmunológiai kor társadalomelméletét. Egyes elméletek szerint azonban a Másik nem eltünik, hanem csak átalakul: inkább a médiahatalomban és a médiától átitatott tömegben kell keresnünk a Másikat, aki/ami ilyen formájában persze már nem válthat ki bennünk olyan természetes reakciót, mint az immunológiai kor alanyaiban.

Ez a természetellenes immunreakció viszont további zavarokat okoz és zárásképp Han e zavarokat és ezek következményeit vázolja fel. Ha a posztimmunológiai korszak teljesítménykényszere vezérel minket, akkor ez folyamatosan arra kényszeríthet, hogy az elért eredményeink után mindig további eredmények elérését kényszerítsük ki magunkból. Ennek következménye a lelki összeomlás, a burnout-szindróma, aminek drasztikus végkimenetele az lesz, hogy a kötelességtudó, teljesíto alany „halálra valósítja magát”. (76)

A Han által leírtakat olvasva talán páran úgy érezhetik, hogy okkal húzhatják ki magukat, mert ők igenis teljes valójukban ki tudnak lépni a hani teljesítménygépezetből és képesek a természetes immunreakciók megfogalmazására. De vajon megszülethetnek-e még a kor emberében Sartre unalommal vegyült undorához, Heidegger szorongásához, Bendeman / Gregor Samsa alkalmazkodási zavarához és Raszkolnyikov bűntudatához hasonló természetes immunreakciók? Aligha, ugyanis a mai kor embere arra predesztináltatott, hogy csak posztimmunológiai reakciókat adhasson világa jelenségeire. E sors még akkor is meghatározza életútját, amikor történetesen a gondolkodó szerepét ölti magára. De persze még ekkor is reménykedhet abban, hogy, még ha csak pillanatokra is, de képes lesz természetes immunválaszok megfogalmazására - persze csak kötelességből. 


\section{Bibliográfia}

Arendt, Hannah. 1981. Vita activa oder Vom tätigen Leben. München: Piper.

Baudrillard, Jean. 1997. A rossz transzparenciája. Esszé a szélsöséges jelenségekröl. Ford. Klimó Ágnes. Budapest: Balassi.

Foucault, Michel. 1990. Felügyelet és büntetés. A börtön története. Ford. Fázsy Anikó - Csűrös Klára. Budapest: Gondolat. 